\title{
NOTES
}

\section{ADMIRALTY: CONTRIBUTION AND THE FEDERAL EMPLOYEES COMPENSATION ACT}

A general rule of admiralty law provides that when a collision is the fault of both parties thereto, the aggregate damages arising out of the collision will be divided and borne equally. ${ }^{1}$ Traditionally, the aggregate damages include payments made by the owners of each ship for personal injuries or damages to cargo aboard either vessel. ${ }^{2}$ The recent case of United States v. Weyerhaeuser S.S. Co. ${ }^{8}$ held, however, that in a division with the United States, the owner of a ship that had collided with a public vessel of the United States could not include payments it had made to a seaman of the government vessel.

The Weyerhaeuser case arose upon cross libels of the Weyerhaeuser Company and the United States for damages resulting from a collision of the S.S. F.E. Weyerhaeuser and the Army dredge Pacific." The trial court found that the collision had been caused by the negligence of both vessels and ordered the damages divided. Weyerhaeuser sought to include in the division 16,000 dollars it had paid to one Reynold Ostrom, a civil servant seaman of the Pacific, in settlement of damages Ostrom claimed for injuries resulting from the collision. The United States, having paid compensation benefits to Ostrom, objected to the inclusion of the 16,000 dollars in the division. ${ }^{5}$ The trial court in-

\footnotetext{
'See The Catharine, 58 U.S. (17 How.) 170 (1854).

The division is usually made by a payment from the vessel least damaged to the vessel most damaged of one-half the difference between their respective damages. See generally GILMORE \& BLACK, ADMIRALTY 402-03, 434-42 (1957).

"See The Chattahoochee, 173 U.S. 540 (1899); The "Alabama" and The "Gamecock," 92 U.S. 695 (1875); The Washington and The Gregory, 76 U.S. (9 Wall.) 513 (1869).

294 F.2d 179 (9th Cir. 1961), cert. granted, 369 U.S. 810 (1962).

- The Weyerhaeuser Company brought its libel against the United States under the Public Vessels Act, 43 Stat. 1112 (1925), as amended, 46 U.S.C. \$§ 781-90 (1958).

'In addition to the $\$ 16,000$, the trial court found that the S.S. F.E. Weyerhaeuser suffered $\$ 27,652.13$ physical and detention damages, for a total of $\$ 43,652.13$, and that the Pacific suffered total damages of $\$ 37,439.26$. Because Weyerhaeuser's damages exceeded those of the United States by $\$ 6,212.87$, one-half this figure, or $\$ 3,106.44$, was ordered paid by the United States to Weyerhaeuser. 294 F.2d at 180 .

If the $\$ 16,000$ is not included, Weyerhaeuser's total is but $\$ 27,652.13$, or $\$ 9,787.13$ less than the United States' total. Presumably the United States is now entitled to an award of one-half the new difference, or $\$ 4,893.56$, to be paid by Weyerhaeuser. It
} 
cluded $^{8}$ the payment and the United States appealed.

The Court of Appeals for the Ninth Circuit reversed, holding that the shipowner could not include the 16,000 dollars in the division. The decision was based on Section 20r (b) ${ }^{7}$ of the Federal Employers Compensation Act, ${ }^{8}$ which purports to make the United States' liability under that statute its exclusive liability to anyone who might otherwise have had, under any other act, a right to recover against the United States on account of a federal employee's injury. The court felt that to allow contribution would conflict with a statutory policy of exclusive liability ${ }^{9}$ and thus concluded that the maritime right had been abrogated by section $201(\mathrm{~b}) . .^{10}$

will be observed that the resulting loss to Weyerhaeuser, and gain to the United States is the sum of the award it has lost $(\$ 3,106.44)$ and the award it inust now pay $(\$ 4,893.56)$. That sum is, of course, $\$ 8,000$, which is one-half the $\$ 16,000$ in dispute.

- Wegerhaeuser S.S. Co. v. United States, 174 F. Supp. 663, as supplemented at 178

F. Supp. 496 (N.D. Cal. 1959).

${ }^{7} 63$ Stat. 861 (1949), 5 U.S.C. $\$ 757$ (b) (1958), is as follows:

"The liability of the United States or any of its instrumentalities under sections 75 s$756,757-781,783-79 x$ and 793 of this tille or any extension thereof with respect to the injury or death of an employee shall be exclusive, and in place, of all other liability of the United States or such instrumentality to the employee, his legal representative, spoure, dependents, next of kin, and anyone otherwise entitled to recover damages from the United States or such instrumentality, on account of such injury or death, in any direct judicial proceedings in a civil action or in admiralty, or by proceedings, whether administrative or judicial, under any other workmen's compensation law or under any Federal tort liability statute: Provided, however, That this subsection shall not apply to a master or a member of the crew of any vessel." (Portions paraphrased or quoted by the court in Weyerhacuser italicized.)

8 Stat. 742 (1916), as amended, 5 U.S.C. $\$ \S 751-803 a$ (1958).

- "The question presented here is a difficult one. Its resolution will abridge either the statutory policy or the maritime law. To allow a third party recovery against the United States on any ground is subversive of the statute limiting liability of the United States. On the other hand, the money paid Ostrom is an element of the total damages suffered by appellee. And failure to apportion such damages is a breach of the maritime rule...." 294 F.2d at $18 \mathrm{x}$.

The court relied heavily on Underwood v. United States, 207 F.2d 862 (1oth Cir. 1953), and Smithers \& Co. v. Coles, 242 F.2d 220 (D.C. Cir. 1957), which held respectively that $\S 201(\mathrm{~b})$ and the parallel section of the Longshoremen \& Harbor Workers Compensation Act, $\S 5,44$ Stat. 1426 (1927), 33 U.S.C. $\S 905$ (1958), excluded an action of the spouse of an injured employee against the employer for consortium. The court said:

"In our opinion the shipowner's right of action is just as dependent upon the cmployee's injury as the wife's clain for loss of consortium ..... If, then, the policy of the statute bars the wife's action for loss of consortium, it should also bar the shipowner's action for contribution.". 294 F.2d at 184.

${ }^{10}$ "Thus it nust be candidly admitted that while the United States once had a duty to othor shipowners to navigate carefully in order not to injure its own emplojees, that duty has been abrogated by the Compensation Act." 294 F.2d at 185. 
It is submitted that the Weyerhaeuser decision is not justified by the terms of section 20r(b), by Supreme Court rulings when the admiralty rule of contribution has conflicted with analogous provisions of other acts, nor by considerations of policy and justice. Turning first to section 201 (b), it seems that the court overlooked the proviso at the end of that section which says: ". . this subsection shall not apply to a master or a member of the crew of any vessel." Senate debate reveals that the proviso's purpose was to negate any implication of a policy to make the FECA the exclusive liability of the United States for seamen's injuries. Senator Morse, sponsor of the proviso, stated:11

"Under existing law, Government-employed seamen have been accorded the right to assert their maritime rights against the United States under the Suits in Admiralty Act and Public Vessels Act .... I feel they should not be deprived of benefits they have enjoyed for many years without opportunity to have their arguments carefully considered by the appropriate committees of Congress ...."

In light of this statutory language and legislative history indicating a policy of non-exclusiveness of the FECA in cases of seamen's injuries, there seems to be little reason for the denial of contribution in the instant case.

Perhaps the Ninth Circuit's misunderstanding of section 20I(b) resulted from its misreading of the Supreme Court decision in Johansen v. United States. ${ }^{12}$ The court cited that case for the proposition that the FECA is the exclusive remedy against the United States of injured seamen employed on public vessels. While Johansen so held, the decision was not based on section 201 (b), but instead on a rather surprising assertion, contradicting Senator Morse, that Congress had never provided seamen on public vessels with a remedy against the United States other than under the FECA, even before the FECA was made

Although the court did not refer specifically to $\S 20 \mathrm{r}(\mathrm{b})$, by necessity it meant that section rather than the FECA in general. The FECA was enacted on September 7, x916. 39 Stat. $74 z$ (1916), as amended, 5 U.S.C. \$§ $751-803$ a (1958). The duty of the United States to other shipowners to navigate its public vessels carefully came into existence afterwards upon the passage of the Public Vessels Act on March 3, 1925. 43 Stat. 1112 (1925), as amended, 46 U.S.C. $\$ 8781-90$ (1958). See note 4 supra. Section 201 (b) was not added to the FECA until October 14, 1949. 63 Stat. 861 (1949), 5 U.S.C. 8757 (b) ( $\left.195^{8}\right)$. Obviously, only $\& 201$ (b) could have repealed rights created by the Public Vessels Act.

${ }_{21} 95$ CONG. REC. 13608 (1949).

12343 U.S. 427 (1952). The court also cited Patterson v. United States, $359^{\prime}$ U.S. 495 (1959), which followed Johansen. 
exclusive by section 20r(b) in $1949.0^{13}$ The Court in Johansen, however, did not suggest that third parties, such as shipowners, had not had rights outside the FECA against the United States before section 20I (b) was passed. ${ }^{14}$ Therefore, Johansen, having been decided in disregard of the statutory policy of non-exclusive liability embodied in the proviso to section 20r(b), can hardly be extended to support a decision which takes away an established right of shipowners. ${ }^{15}$ This conclusion is reinforced by the additional fact that Johansen seems clearly to have been wrongly decided.18 Four Justices dissented in Johansen, agreeing with Senator Morse that seamen had remedies against the Government outside the FECA, and that the proviso to section 201 (b) preserved those remedies. ${ }^{17}$ As the dissent indicated, none of the relevant statutes or decisions supported the Johansen majority. ${ }^{18}$ For example, in Fleet Corp. v. Lustgarten ${ }^{10}$ the Supreme Court had acknowledged a right of government seamen to recover against the United States outside the FECA. In view of the strong doubts expressed, it is difficult to justify an extension of Joharnen to abrogate a shipowner's right to contribution.

The Weyerhaeuser decision, indefensible as it is under the proviso to section 20r(b), could not be defended even if that proviso did not apply. The Supreme Court's treatment of two other statutes that conflict with the admiralty doctrine of contribution in the same fashion as does Section 201(b) of the FECA points to the allowance of contribution in Weyerhaeuser. ${ }^{20}$

\footnotetext{
${ }^{12}$ See note 10 supra.

${ }^{14}$ Indeed, the court in Weyerhaetuser admitted that the United States had once had a duty to shipowners to navigate carefully in order not to injure its own employees. See note 10 supra.

Furthermore, the court in the instant case relied on Underwood v. United States, 207 F.2d 862 (1oth Cir. 1953), note 9 supra, and said, 294 F.2d at 184 n.3: "Wc agree with the reasoning of the Tenth Circuit. There the court said: It is significant, we think, that the Congress chose to speak in terms of liability of the government, not in terms of remedies or rights of action, and in doing so, it gave a right of action only to the extent that it saw fit to relax governmental immunity from any liability.' .. 207 F.2d 862, 864." Johansen, however, did not hold that the United States' liability was exclusive, but only that the seaman's remedy was exclusive.

${ }^{15}$ See notes 10 \& 14 suppra.

${ }^{16}$ Substantially the same may be said for Patterson v. United Statex, 359 U.S. 495 (1959), note 12 suspra.

${ }_{12} 343$ U.S. at 441 .

${ }^{16}$ See, e.g., Johnson v. United States, 186 F.2d 120 (4th Cir. 1950). See Gibbs v. United States, 94 F. Supp. 586 (N.D. Cal. 1950), for 2 review of the zuthorities.

10280 U.S. 320 (1929).

${ }^{30}$ There seem to be no cases on the conflict between the FECA and contribution in
} 
Under the Harter Act, ${ }^{21}$ carriers are relieved of all liability to the owners of cargo for negligent navigation. ${ }^{22}$ Cargo owners who have suffered loss in a collision, however, may sue any non-carrying vessel that is partly responsible for their losses. The Supreme Court has then allowed the non-carrying vessel in such cases to have contribution from the carrying vessel if the latter were by its negligence jointly responsible for the loss. ${ }^{23}$ Thus, by holding shipowners liable to other ships for contribution for the cargo losses, despite the statute which limits their liability to the cargo owners, the Court has evinced a strong policy of liability of shipowners to other ships for damages caused by the negligent navigation of their own ships. Indeed, the Court has considered this policy so important that it has refused to let shipowners pass their liability for contribution back to cargo owners by means of contract. In United States v. Atlantic Mut. Ins. Co., ${ }^{24}$ the Court held invalid a clause in an ocean bill of lading that required the cargo owner to indemnify the ship for any amount it might lose by reason of a recovery

admiralty. In The West Point, 71 F. Supp. 206 (E.D. Va. 1947), however, a conflict very similar was decided in favor of contribution. In that case two naval officers of the United States were injured when the public vessel they were aboard collided with a ferry boat. The officers brought suit against the ferry boat, her owners, and the United States. Their suit against the Government was dismissed on the ground that members of the armed services cannot sue the Government under the Public Vessels Act, note 4 supra. (Service men are not covered by the FECA, but have a separate compensatory program.) The court, however, allowed the ferry owners to implead the United States for contribution. In a later disposition of the case, $83 \mathrm{~F}$. Supp. 680 (E.D. Va. 1949), the United States was held liable to the owners of the ferry for contribution for the damages paid to the officers.

${ }_{22} 27$ Stat. 445 (1893), 46 U.S.C. $\$ \S 190-96$ (1958). The statements in the text concerning the Harter Act apply equally to the Carriage of Goods by Sea Act, 49 Stat. 1207 (1936), 46 U.S.C. $\$ \S 1300-15$ (1958), which has superseded the Harter Act in many areas. See generally GiLmore \& BLACK, AdMIRALTY I 19-69 (1957).

${ }^{29}$ Section 3 of the Harter Act, 27 Stat. 445 (1893), 46 U.S.C. § 192 (1958), provides:

"If the owner of any vessel transporting merchandise or property to or from any port in the United States of America shall exercise due diligence to make the said vessel in all respects seaworthy and properly manned, equipped, and supplied, neither the vessel, her owner or owners, agent, or charterers, shall become or be held responsible for damage or loss resulting from faults or errors in navigation or in the management of said vessel ...."The analogous provision of the Carriage of Goods by Sea Act, $\S_{4}(2)(a), 49$ Stat. 1210 (1936), 46 U.S.C. $\S 1304(2)$ (a) (1958), saves harmless a carrier or his vessel from liability for any: "Act, neglect, or default of the master, mariner, pilot, or the servants of the carrier in the navigation or in the management of the ship ...."

${ }^{88}$ The Chattahoochee, 173 U.S. 540 (1899).

${ }^{24} 343$ U.S. 236 (1952). 
by the cargo owner from a non-carrier vessel for cargo damages which are included in the damages to be divided between the two ships. ${ }^{25}$

Another statute which conflicts with admiralty contribution is the Longshoremen \& Harbor Workers Compensation Act. ${ }^{20}$ That act protects covered employers with an exclusive liability clause similar to section 201 (b), without the proviso. ${ }^{27}$ There is a split of authority, however, as to whether the exclusive liability clause bars shipowners from dividing with employers payments made to longshoremen for injuries caused by the joint fault of shipowner and employer. ${ }^{28}$ Inasmuch as longshoremen are rarely involved in ship collisions, the split of authority may never be resolved, since the Supreme Court has held that admiralty contribution is not available in non-collision cases. ${ }^{20}$ Despite the fact that the question of contribution has thus been rendered moot, a later line of cases has effectively robbed the employer of his exclusive liability under the L\&HWCA in those instances where he is jointly responsible with a shipowner for his employee's injury. In Crawford v. Pope $\mathcal{E}^{3}$ Talbot, $^{30}$ the Third Circuit recognized an implied

\footnotetext{
${ }^{25}$ The court in the instant case admitted that the Harter Act decisions are strong authority for division despite the FECA, but purported to distinguish them on the ground that the Harter Act was not intended to affect a shipowner's liability to third parties, while the FECA specifically governs the rights of third parties growing out of an injury to a federal employee. 294 F.2d at 185 . This distinction, of course, assumes the controlling applicability of $\S 201(\mathrm{~b})$, without consideration of the proviso thereto.

${ }^{28} 44$ Stat. 1424 (1927), as amended, 33 U.S.C. $\$ \S$ gor-50 (1958).

${ }^{27} \S 5,44$ Stat. 1426 (1927), 33 U.S.C. § 905 (1958).

${ }_{28}$ Contribution allowed: Barbarino v. Stanhope S.S. Co., I5 I F.2d 553 (2d Cir. I945); New York \& Porto Rico S.S. Co. v. Lee's Lighters, 48 F.2d 372 (E.D.N.Y. I930); Barber S.S. Lines v. Quinn Bros., 94 F. Supp. 212 (Mass. 1950); Portel v. United States, 85 F. Supp. $45^{8}$ (S.D.N.Y. 1949); The S.S. Samovar, 72 F. Supp. 574 (N.D. Cal. 1947); The Tampico, 45 F. Supp. I74 (W.D.N.Y. 1942); Rederii v. Jarka Corp., 26 F. Supp. 304 (Me. 1939). Contribution denied: American Mut. Liab. Ins. Co. v. Matthews, I 82 F.2d 322 (2d Cir. 1950); Johnson v. United States, 79 F. Supp. 448 (Ore. 1948); Standard Wholesale Phosphate \& Acid Works v. Rukert Terminals Corp., 193 Md. 20, 65 A.2d 304 (1949).

${ }^{28}$ Halcyon Lines v. Haenn Ship Ceiling \& Refitting Corp., 342 U.S. 282 (1952). In the Halcyon Lines case the Court specifically refused to decide whether the L\&HWCA barred the claim of contribution, reserving that question until properly before it in a collision case. However, certain language in the Court's opinion indicates that the Court might decide in favor of contribution in a collision case:

"Where two vessels collide due to the fault of both, it is established admiralty doctrine that the mutual wrongdoers shall share equally the damages sustained by each, as well as personal injury and property damage inflicted on innocent third parties." 342 U.S. at 284 .

${ }^{30} 206$ F.2d 784 (3d Cir. 1953). Later, in the case of Brown v. American. Hawaiian S.S. Co., 2 I I F.2d 16, 18 n.4 (3d Cir. 1954), the same court stated that it
} 
contract of indemnity under which shipowners may recover from an employer the total payments made to a longshoreman for injuries. In Ryan Co. v. PanAtlantic Corp. ${ }^{31}$ the Supreme Court adopted this doctrine as its own, holding that a shipowner could recover from a longshoreman's employer upon an implied warranty to stow cargo in a reasonably safe fashion. The result has been that the negligent employer now pays any damages his employee recovers from a shipowner, despite the employer's "exclusive liability" protection. ${ }^{\mathbf{3 2}}$

The exception to the United States' liability for negligence to shipowners $^{88}$ made in Weyerhaeuser unjustly casts the entire burden of the government seaman's injury upon the private shipowner. ${ }^{84}$ This result is unfair, not ouly because the United States was jointly at fault, but also because the United States could have had contribution from Weyerhaeuser had Ostrum been a seaman of the private vessel, recovering his damages from the government. The general policy of compensation statutes, which results in providing an employee only one remedy against his employer, does not require the abrogation of the shipowner's established, independent right of contribution. ${ }^{35}$ The

would be difficult for it to conceive of a situation where there would not be an implied contract upon which indemnity could be based when stevedores were on and about a ship.

3120 U.S. 124 (1956).

82 The Supreme Court re-endorsed the Ryan decision in several cases. Waterman S.S. Corp. v. Dugan \& McNamara, Inc., 364 U.S. 421 (1960) ; Crumady v. The Joachim Hendrik Fisser, 358 U.S. 423 (1959); Weyerhaeuser S.S. Co. v. Nacirema Operating Co., 355 U.S. 563 (1958).

The Ryarz and Crumady cases establisb that the employer's implied warranty includes at least negligent operation of equipment aboard ship and negligent failure to inspect for defects. Lower court decisions indicate that employers must be almost completely free of negligence to avoid liability. See, e.g., Metropolitan Stevedore Co. v. Dampskisaktieselskabet Int'l, 274 F.2d 857 (9th Cir. 1960); Royal Mail Lines, Ltd. v. Peck, 269 F.2d 875 (9th Cir. 1959); American Export Lines v. Revel, 266 F.2d 82 (4th Cir. 1959); Calmar S.S. Corp. v. Nacirema Operating Co., 266 F.2d 79 (4th Cir. 1959).

See generally, Gizmore \& Black, Admiralty 358-74 (1957).

"See notes 4 \& 10 supra for the statute upon which liability is founded.

st The United States will be relieved of all liability to its injured employee in the instant case. Under $\$ 27$ of the FECA, 39 Stat. 747 (1916), 5 U.S.C. $\$ 777$ (1958), the United States can recover the compensation it has paid an employee out of any recovery or settlement the employee has had from a third party. In Randall v. United States, 282 F.2d 287 (D.C. Cir. 1960), cert. denied, 365 U.S. 813 (196r), such a recovery was allowed despite the fact that the United States was by its negligence jointly responsible for the employee's injury.

The result is that in the instant case the FECA is not the government's "exclusive" liability; in essence the Government has no liability. Thus, the United States is better off as a joint tort-feasor than when no one is at fault.

as See notes 1o \& 15 supra. 
justification for making compensation the employee's exclusive remedy lies in the "bargain" that is said to underlie compensation statutes." Under these statutes employers stabilize the costs of industrial injuries by making relatively small, regularized payments to employees for injuries regardless of fault. In return for sure compensation, employees give up an uncertain, but possibly large common law recovery. However, employees' rights against third parties are not cut off by the "bargain." On the contrary, employees may sue third parties for negligence. ${ }^{38}$ If, as in Weyerhaeuser, the third party is then denied his independent right of contribution from the United States, it is he, rather than the parties to the "bargain," who must bear the expense of the compensation system.

Admiralty contribution must be distinguished from any common law or statutory right of contributions in which one tort-feasor is subrogated to the injured parties' rights against the other tort-feasor. Admiralty contribution, being but one aspect of the rights to divide the damages of a collision, is based upon as independent duty every vessel owes every other vessel to navigate with reasonable care. See Erie R.R. v. Erie Transp. Co, 204 U.S. 220, 226 (1907).

Non-admiralty contribution from employers has been held barred under state compensation laws containing an exclusive liability provision similar to $\$ 201(\mathrm{~b})$. Without the proviso the primary reason given for barring contribution has been that covered employers are not "tort-feasors," since they are not liable in tort to their employees. Therefore there is no basis of joint liability upon which subrogation can be founded. See 2 LARSON, WORKMEN's COMPENSATTON $\$ \S 76.21-.22$ (Supp. 1961). Obviously, this reasoning is irrelevant to admiralty contribution.

s8 See 2 LARSON, WORKMEN's CoMpensatTon § 65.10 (Supp. 196r).

37 See 2 LARSON, WORKMEN'S COMPENSATION $\$ \S 7$ 1.10.-.20 (Supp. 1961).

13 This is precisely what happened in the Weyerhaeuser case. Cf. note 34 supra. 